\title{
Role of flow-through lakes in reducing pollutants outgoing from rural areas
}

\author{
Marlena Wiktorska ${ }^{1, *}$, and Stawomir Szymczyk ${ }^{1}$ \\ ${ }^{1}$ University of Warmia and Mazury, Department of Water Resources, Climatology and Environmental \\ Management, Plac Łódzki 2, 10-719 Olsztyn, Poland
}

\begin{abstract}
This study assessed the water quality in Lake Wydmińskie (Warmińsko-Mazurskie Voivodeship) based on the content of both organic and inorganic pollutants flowing into the lake with water from drainage systems. The study demonstrated that the water flowing into the lake through drainage ditches that drain the improved part of the catchment area of the lake, was a potential source of diffuse pollutants and excess chemical components were deposited in the lake which could lead to its degradation. The most polluted water was found in the main tributary and the lake bay fed by its water. For this reason, it was concluded that the greatest problem was the area-wide sources of pollutants outgoing from agricultural areas. It was also found that water flowing out of the lake was of a considerably better quality than water flowing into the lake through the ditches. This clearly indicates the accumulative role of the lake on the route of pollutant migration from agricultural sources.
\end{abstract}

\section{Introduction}

Environmental conditions of each lacustrine system are determined by the type of the lake and its exposure to various environmental factors. Therefore, the quality of surface waters is not only determined by natural processes (meteorological conditions, erosion and weathering, etc.) but also by anthropogenic (urban, industrial, and agricultural) impact [1]. The lacustrine ecosystem is exceptionally sensitive to external factors, and it is very easy to disturb its state of equilibrium. Population growth, agricultural practices and wastewater flowing from urban areas have led to an increased nutrient outflow to water bodies which, in many cases, resulted in accelerated eutrophication [2]. Lakes and water bodies, particularly urban ones, without adequate protection become pollutant absorbers, which can lead to their degradation [3]. An excess of nutrients and organic carbon in the soil and water due to industrial, agricultural and other human activities results in widespread environmental problems [4]. Organic matter (OM) serves numerous geochemical and ecological functions in inland waters and may affect water quality. Various parameters of aqueous $O M$ are measured using various methods, as no single analytical tool can provide final structural or functional information about it [5]. Waters outgoing from agricultural

*Corresponding author: marlena.wiktorska@uwm.edu.pl 
areas supply the lake with huge amounts of inorganic anions, such as phosphates, nitrates and ammonia, organic nitrogen compounds and heavy metals [6]. The chemical composition of water in small bodies and lakes provides important information on the sources of dissolved ions and hydrogeochemical processes and on anthropogenic activities affecting the lacustrine environment [7]. Many natural factors (physical, biological, geographical, hydrological and meteorological) impact the chemistry of water bodies [8]. However, the greatest hazard is posed by the intensification of agriculture [9].

\section{Materials and methods}

The analysis of the quality of water in Lake Wydmińskie as well as in its tributaries and the outflow, was carried out from November 2015 to October 2018. The measurements and sampling were performed at monthly frequency. The lake is located in north-eastern Poland $\left(\mathrm{N}: 54^{\circ} 00^{\prime} \mathrm{E}: 22^{\circ} 00^{\prime}\right.$ ) in the Warmińsko-Mazurskie Voivodeship, in the commune of Wydminy. The maximum depth of the lake is $9.8 \mathrm{~m}$, while the average depth is $2.98 \mathrm{~m}$. The area of the lake is relatively large, as the lake surface occupies an area of 336.6 ha (actual value), and the geodetic area is 377.46 ha (determined by average value of the isobath $0 \mathrm{~m}$ ). The shape of the lake is very elongated (Fig. 1).

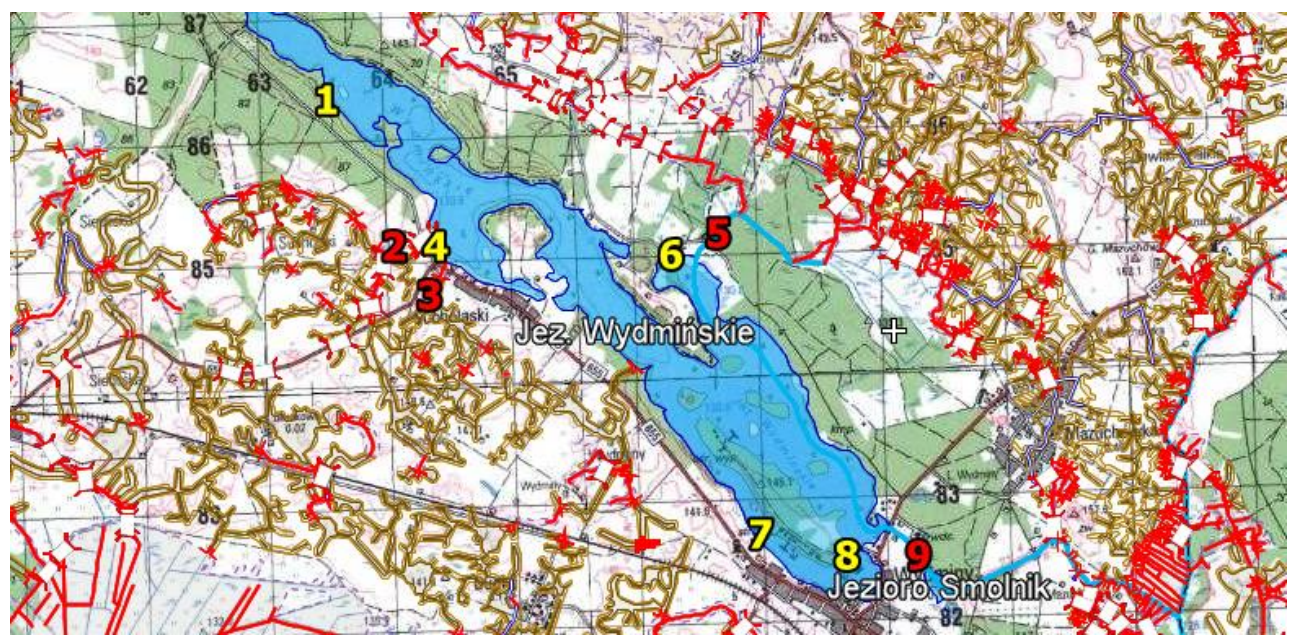

Fig. 1. The sites of water sampling (based on Geoportal).

The total catchment area of Lake Wydmińskie is approx. $34 \mathrm{~km}^{2}$. Within the total catchment area, agricultural land is predominant, particularly in the catchment basin of the main tributary in the vicinity of the village of Mazuchówka. The immediate catchment area of the lake occupies a relatively small area and is mainly overgrown by forests. The catchment area is drained through a system of watercourses and drainage ditches. The monitoring point in the part of the catchment area located in the forest (1) is a water intake point located in an area overgrown with forest vegetation. Tributary I (2) which flows into the lake on the edge of Sucholaski is a drainage ditch that discharges water from a small part (with an area of approx. $2.4 \mathrm{~km}^{2}$ ) in the western part of its drainage catchment. This is a typically agricultural area. Over the section near the outlet, the ditch channel is shallow $(0.5-0.7 \mathrm{~m}$ of depth) and the bed is covered with stones and gravel. Tributary II (3) is located directly in Sucholaski and drains a small part of the catchment area of approx. $1.5 \mathrm{~km}^{2}$. It is a typically agricultural catchment area with a large proportion of meadows and pastures as well as forest plantings on post-agricultural areas. Water from agricultural land is discharged through the drainage system that flows into a small pond from which 
water flows into the lake through a ditch. Over the section near the outlet, the drain channel is shallow (0.3-0.5 m) and stony. The monitoring point in the locality of Sucholaski (4) was located near a publicly accessible village beach. This is an area potentially susceptible to high anthropogenic pressure due to its proximity to rural buildings and its recreational nature. The largest tributary of the lake is the main drainage ditch (5) which drains the eastern part of the catchment area of approx. $18.5 \mathrm{~km}^{2}$. This is an extensive area with a dense system of feeder ditches. The catchment area is typically agricultural, with a large proportion of meadows and pastures. Near the outlet to the lake, the main ditch bed has a width of approx. $3.5 \mathrm{~m}$ and a depth of over $0.5 \mathrm{~m}$. The ditch banks are overgrown with common reed (Phragmites australis) and broadleaf cattail (Typha latifolia) and the water surface during the entire growing period was completely covered with the common duckweed (Lemna minor). The monitoring point in the bay (6) was located behind the outlet of the main tributary. The area of the bay is heavily overgrown with common reed rushes. The monitoring point on the bridge (7) linking the shore of the lake with its largest island is situated near the housing development in Wydminy. Water samples at this point were collected from the pelagic zone. The monitoring point on the island (8) was located at the village beach, in the immediate vicinity of the housing development in Wydminy. Water samples at this point were collected from the littoral zone. The outflow from the lake (9) is located in Wydminy. It is a regulated watercourse with a length of approx. $2 \mathrm{~km}$. Its channel at the place of measurement has a width of approx. $2.5-3 \mathrm{~m}$, the depth is over $0.5 \mathrm{~m}$, and the bed is covered with stones and gravel. Directly in the field, at the designated monitoring points in water, the following were determined: total dissolved substances $(T D S)$, dissolved oxygen $(D O)$ content, water temperature and the $\mathrm{pH}$ values (using a YSI 6600 multiparameter sonde). Water samples were collected to polyethylene $3 \mathrm{dm}^{3}$ bottles; after the stabilisation, the samples were delivered to the laboratory where the following were determined: 5-day Biological Oxygen Demand $\left(B O D_{5}\right)$ using the OxiToP ${ }^{\circ}$ Control method, the Chemical Oxygen Demand $\left(C O D_{C r}\right)$ using the dichromate method, dry residue content after evaporation and drying at a temperature of $105^{\circ} \mathrm{C}$, and the residue on ignition (ash components) after combustion in a muffle furnace at $550^{\circ} \mathrm{C}$ [10]. The obtained results were subjected to a statistical analysis using Statistica software ver. 13 PL; the normality of data distribution was determined using the Shapiro-Wilk test at $\mathrm{p} \leq 0.05$; diagrams of average values along with non-outlying maximum and minimum values were developed (for the analysis of $\mathrm{pH}$ values, the median was assumed to be the basis); homogeneous groups were determined based on the (post-hoc) Duncan's test. Homogeneous groups are groups with average values that do not differ statistically. This test determined these groups and defined between which monitoring points there are statistically significant differences in the level of analyzed pollutants.

\section{Results}

The variability of the values of analysed indices of pollutants of water in Lake Wydmińskie and its tributaries and the outflow was determined by the type of water (drainage ditches and the lake) and primarily by the impact of the method of managing the lake catchment area (Fig. 2-5). Total Dissolved Solids (TDS) is a water quality parameter that determines the concentration of dissolved organic and inorganic chemical substances in water. High values of this index can indicate poor living conditions of organisms in the analysed aquatic environment as well as a poor water quality for crop irrigation and unsuitability of the water for consumption [11]. In the lake (except the bay) and in the outflow, they were at a level ranging from approx. $0.25 \mathrm{~g} \cdot \mathrm{dm}^{-3}$ to approx. $0.33 \mathrm{~g} \cdot \mathrm{dm}^{-3}$. In the tributaries and in the bay, they were significantly higher (from approx. $0.38 \mathrm{~g} \cdot \mathrm{dm}^{-3}$ to $0.54 \mathrm{~g} \cdot \mathrm{dm}^{-3}$ ) (Fig. 2). None of these values exceeds the range of limit values specified by the Food and Agriculture 
Organizations of the United Nations (FAO) [12] $\left(2 \mathrm{~g} \cdot \mathrm{dm}^{-3}\right)$; in addition, it was observed, only for tributary II, that the standards specified by the World Health Organization (WHO) [13] $\left(0.5 \mathrm{~g} \cdot \mathrm{dm}^{-3}\right)$ were slightly exceeded. This is a watercourse with a rocky bed and an intense water flow; for this reason, the chemical pollutants contained in the water do not accumulate in sediments but are transported to the lake. However, a high imbalance between the TDS value in the water of the lake and its outflow and in the water of tributaries and the bay should be noted. Water in the lake and in the outflow is characterised by significantly lower values of this index. No significant differences in the TDS values were observed between particular measuring points located in most parts of the lake (except the bay), which indicates no variation in the intensity of the pressure of particular types of catchment area on the lake. Water collected from the points located in the vicinity of Sucholaski and Wydminy was characterised by relatively low TDS values, which may indicate slight human pressure exerted by these locations, even though an increased impact of human activities could be expected from them. The water least loaded with dissolved substances was found in the part of the lake with the lowest human pressure, with a forest area located in the immediate catchment area of the lake. The water outgoing from the lake also contained relatively low concentrations of dissolved substances, even though that part of the lake is located under a busy regional road which is a potential source of linear pollutants. The seasonal variability of water $\mathrm{pH}$ values is determined by the weather conditions which, in turn, determines the availability of the main ions in water. The $\mathrm{pH}$ affects both the solubility of many substances and the activity of most biological systems. The low $\mathrm{pH}$ value facilitates the transition of many substances, e.g. heavy metals, sulphur compounds, and nutrients into active forms $[14,15]$. The $\mathrm{pH}$ values in the analysed water were similar at all monitoring points (Fig. 3); however, it is necessary to note their very high variability whose extreme values exceeded the limits specified by the WHO (6.5-8.5) and the FAO (6.0-8.5). This indicates a periodic excess of chemical pollutants, both acidic and alkaline. Particularly unfavourable is a decrease in the $\mathrm{pH}$ value below 6.5 , which in combination with oxygen deficits results in the predominance of anaerobic reduction processes in the aquatic ecosystem, leading to the formation of substances adversely affecting aquatic organisms.
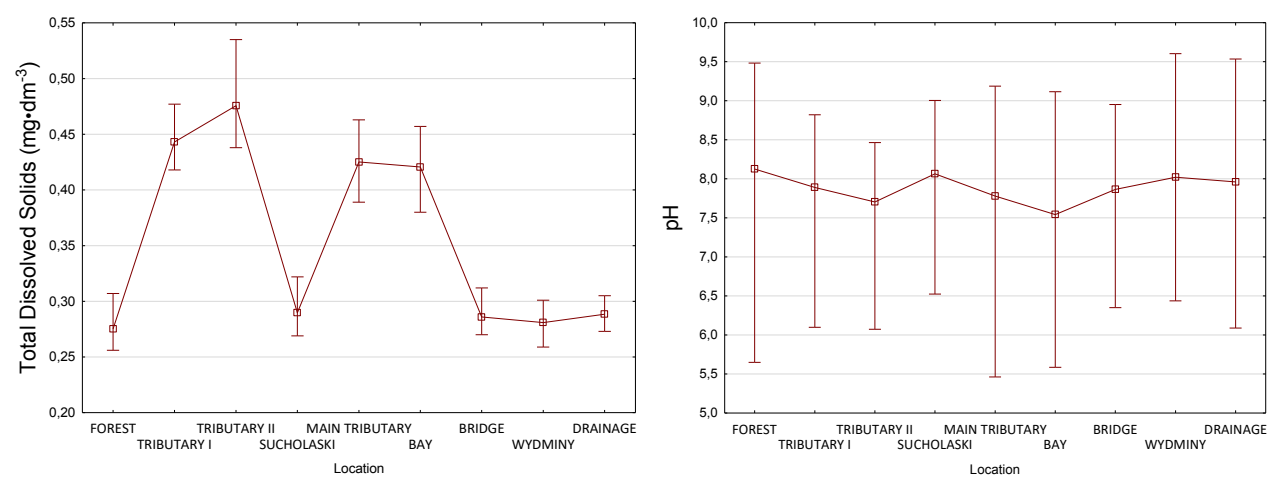

Fig. 2. The effect of the catchment area management method on the $T D S$ values and the $\mathrm{pH}$ in the water of tributaries, outflow and in particular parts of the lake.

Dry residue is an indicator of the contents of solids and substance dissolved and suspended in water, while the residue on ignition determines the mineral substance content. The difference between these indices allows the organic compound content of water to be approximately estimated. The trend in the dry residue and residue on ignition contents was similar to that for the TDS index, with significantly higher values noted in the lake tributaries and in the bay (Fig. 3). The water in the monitored (analysed) parts of the lake 
and in the outflow were characterised by a lower content and did not differ from each other significantly (dry residue ranged from approx. $250 \mathrm{mg} \cdot \mathrm{dm}^{-3}$ to approx. $350 \mathrm{~g} \cdot \mathrm{dm}^{-3}$, and the mineral residue from approx. $150 \mathrm{mg} \cdot \mathrm{dm}^{-3}$ to approx. $250 \mathrm{mg} \cdot \mathrm{dm}^{-3}$ ). Based on the above indices, it can be assumed that irrespective of the type (flowing waters and the lake) of the analysed waters, organic compounds accounted for an average of approx. $30 \%$ of all substances. Significantly higher values of the analysed indices in water of all drainage ditches draining the improved agricultural catchment area and of the bay in relation to other parts of the lake indicate the very great contribution of agriculture to the loading of lake water with mineral and organic substances (dry residue ranged from approx. $375 \mathrm{mg} \cdot \mathrm{dm}^{-3}$ to approx. $600 \mathrm{mg} \cdot \mathrm{dm}^{-3}$, and the mineral residue from approx. $260 \mathrm{mg} \cdot \mathrm{dm}^{-3}$ to approx. $450 \mathrm{mg} \cdot \mathrm{dm}^{-3}$ ). Skonieczek et al. [16] also demonstrated in their study a clear effect of the method of managing the catchment area on the contents of dry residue and of mineral substance residue on ignition. The highest content was found in the water of tributaries from the drainage system that represent the agricultural catchment area (dry residue of 635-656 mg $\cdot \mathrm{dm}^{-3}$; mineral substances: $512-572 \mathrm{mg} \cdot \mathrm{dm}^{-3}$ ), while at other points, the values ranged from 233 to $470 \mathrm{mg} \cdot \mathrm{dm}^{-3}$ and from 161 to $386 \mathrm{mg} \cdot \mathrm{dm}^{-3}$, respectively. The results obtained by these authors are in line with the trends revealed in the results of own research. On the other hand, Sobczyńska-Wójcik [17] found that the lacustrine ecosystem of Nowe Włóki exhibited a stable nature in terms of dry residue and mineral residue contents (the average dry residue content ranged from 210 to $235 \mathrm{mg} \cdot \mathrm{dm}^{-3}$, and the ash component content ranged from 130 to $157 \mathrm{mg} \cdot \mathrm{dm}^{-3}$ ). Similar conclusions can be drawn based on the results of own research.
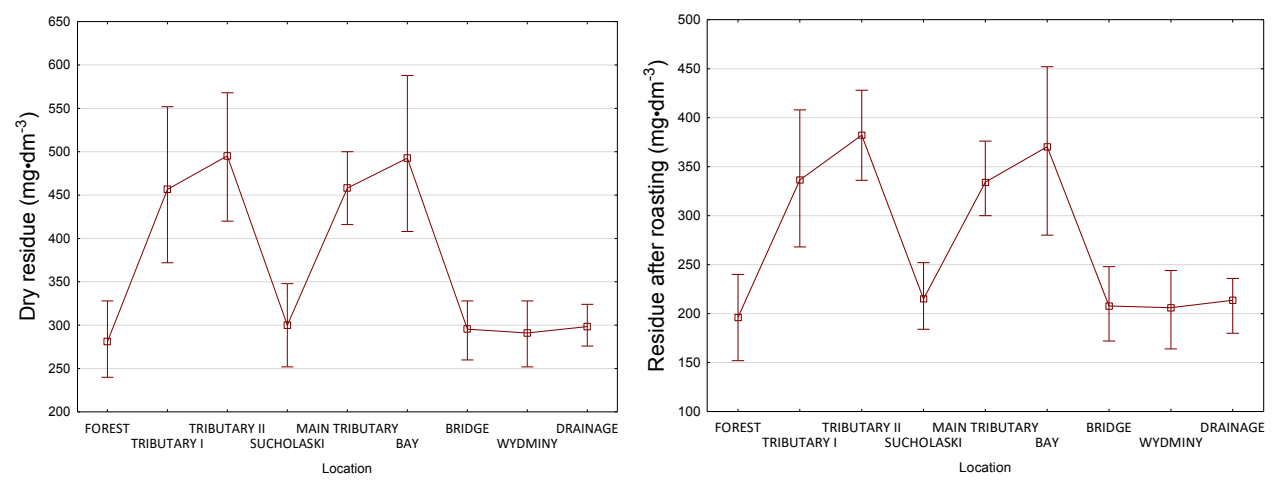

Fig. 3. The dry residue and residue on ignition contents in the water of tributaries, outflow and in particular parts of the lake.

Chemical Oxygen Demand (COD) and Biological Oxygen Demand (BOD) are traditional, commonly used indicators for the assessment of the organic matter content of water. They are used to determine the organic enrichment by oxygen-absorbing substances [5]. The difference between these indicators is that the COD comprises both the biodegradable and non-degradable fractions, while the BOD is limited to the determination of the amounts of readily biodegradable substances [18]. Having analysed the distribution of COD values during the study period in the water of Lake Wydmińskie, significantly higher values of this indicator were found in the lake tributaries and in the bay fed by the main tributary. It follows from the above that the tributaries may pose a potential hazard to the analysed water body through the deposition of pollutants. The COD values in the water of tributary I range from approx. $45 \mathrm{mg} \cdot \mathrm{dm}^{-3}$ to $80 \mathrm{mg} \cdot \mathrm{dm}^{-3}$, tributary II (from approx. $31 \mathrm{mg} \cdot \mathrm{dm}^{-3}$ to $65 \mathrm{mg} \cdot \mathrm{dm}^{-3}$ ), the main tributary from approx. $50 \mathrm{mg} \cdot \mathrm{dm}^{-3}$ to approx. $98 \mathrm{mg} \cdot \mathrm{dm}^{-3}$, and in the water of the bay from approx. $55 \mathrm{mg} \cdot \mathrm{dm}^{-3}$ to $89 \mathrm{mg} \cdot \mathrm{dm}^{-3}$ (Fig. 4). In other monitoring points located in various parts of the lake and in the outflow, the index values ranged from 
approx. $30 \mathrm{mg} \cdot \mathrm{dm}^{-3}$ to $40 \mathrm{mg} \cdot \mathrm{dm}^{-3}$. Diffuse pollutants are transferred from agricultural land to drainage ditches and large water reservoirs, which results in significant deterioration in the quality of water in rivers and lakes [19]. This type of pollutants causes serious problems due to their large scale and diffuse nature. Moreover, their migration in the environment is more difficult to control than that of point pollutants [20]. A similar trend was also noted for the BOD; however, the values of this indicator in water of two smaller tributaries, as opposed to the COD, did not differ significantly from these values in water in other points of the lake; moreover, tributary II was characterised by the lowest BOD value of all monitoring points. This indicates that the water of this watercourse contained a much lower readily biodegradable fraction represented by the BOD indicator than at other monitoring points.
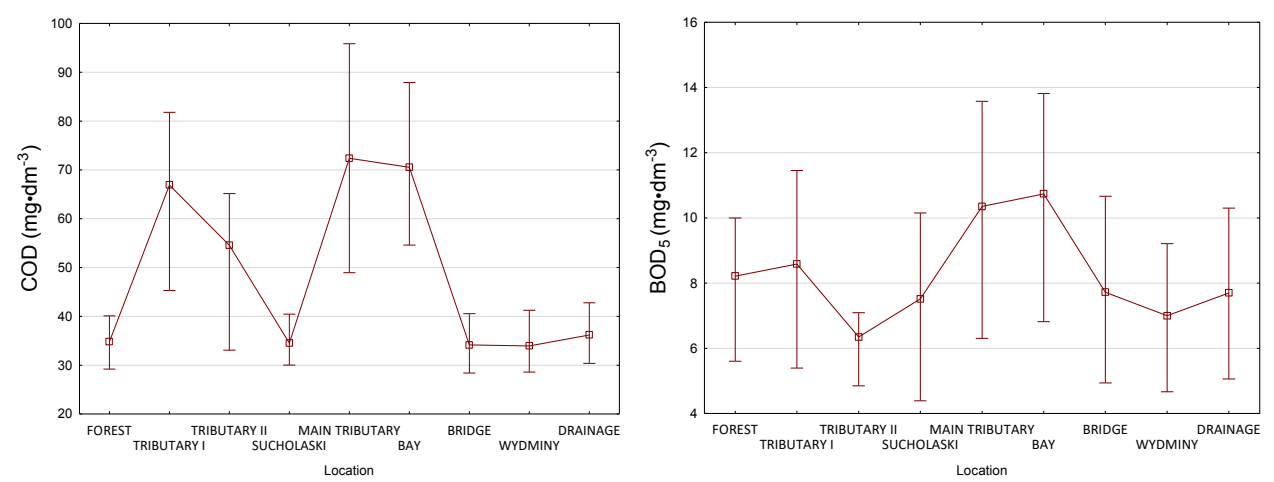

Fig. 4. $\mathrm{COD}$ and $\mathrm{BOD}_{5}$ values in water of the tributaries, outflow and in particular parts of the lake.

Water temperature is the most important indicator of the ecological environment of the lake and is used to determine changes between various factors of water quality (it affects inter alia the dissolved oxygen content of water, the $\mathrm{pH}$ and the development of phytoplankton), which provide a basis for inspections and the improvement of ecological environments of lakes [21]. No statistically significant differences were noted in the average water temperature between the analysed monitoring points, although it was observed that in the water of tributaries and the bay, the temperature was lower than at other points. Tributary III was characterised by the lowest temperature; however, it should be noted that in the summer periods, it was dried up, which prevented measurements and disturbed the comparative assessment. The low levels of oxygen dissolved in water $\left(0-8 \mathrm{mg} \cdot \mathrm{dm}^{-3}\right)$ are due to severe water pollution, mainly with organic matter and are reflected in high values of Biological or Chemical Oxygen Demand in the water. The high levels of dissolved oxygen $\left(12-15 \mathrm{mg} \cdot \mathrm{dm}^{-3}\right)$ may result from an excessive growth of algae and macrophytes, which is associated with intensive photosynthesis processes. In turn, the average range of the values for oxygen dissolved in water $\left(8-12 \mathrm{mg} \cdot \mathrm{dm}^{-3}\right)$ is usually an indicator of a properly functioning ecosystem [11]. In almost all water analyses the dissolved oxygen content was similar to values which indicate a properly functioning ecosystem. Only the waters in the main tributary and in the bay were characterised by a significantly lower content of dissolved oxygen (which did not exceed $10 \mathrm{mg} \cdot \mathrm{dm}^{-3}$, while average values amounted to approx. $7 \mathrm{mg} \cdot \mathrm{dm}^{-3}$ ). This indicates a large amount of substances absorbing oxygen in biochemical processes in the water, which is confirmed by the $\mathrm{COD}$ and $\mathrm{BOD}_{5}$ values. 

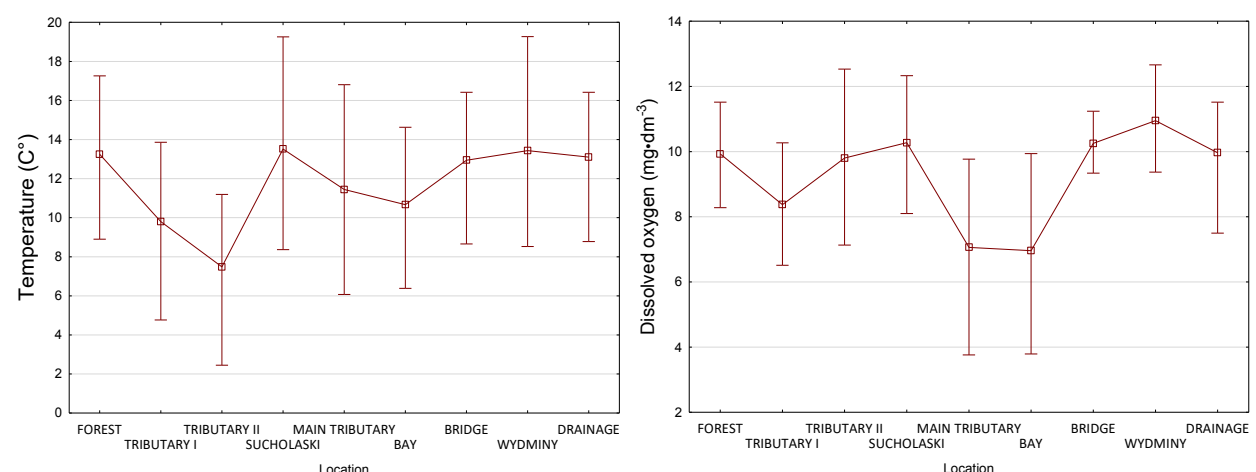

Fig. 5. Water temperature and the dissolved water oxygen content of the tributaries, outflow and particular parts of the lake.

Homogeneous groups contained in table 1 confirm the statistically significant trends that were identified in results in the graphs (Fig. 2-5). In most cases, there was obtained a homogeneous groups consisting of tributaries lakes and bay, which was characterized by significantly higher impurities in comparison to the second homogeneous group consisting of the other monitoring points.

Table 1. Homogeneous groups of the analysed indices based on a (post-hoc) Duncan test.

\begin{tabular}{|c|c|c|c|c|c|c|c|c|}
\hline No. & Location & $\boldsymbol{T D S}$ & DR & RoI & $\boldsymbol{C O D}$ & $\boldsymbol{B O D}_{\boldsymbol{5}}$ & Temp. & $\boldsymbol{D O}$ \\
\hline 1 & Forest & $0.281 \mathrm{a}$ & $287 \mathrm{a}$ & $203 \mathrm{a}$ & $33.84 \mathrm{a}$ & $7.7 \mathrm{ab}$ & $12.92 \mathrm{a}$ & $9.95 \mathrm{ab}$ \\
\hline 2 & Tributary I & $0.446 \mathrm{bc}$ & $460 \mathrm{bc}$ & $333 \mathrm{~b}$ & $67.62 \mathrm{bc}$ & $7.8 \mathrm{ab}$ & $9.74 \mathrm{a}$ & $8.37 \mathrm{bc}$ \\
\hline 3 & TributaryII & $0.474 \mathrm{c}$ & $513 \mathrm{c}$ & $396 \mathrm{c}$ & $58.18 \mathrm{~b}$ & $6.1 \mathrm{a}$ & $7.46 \mathrm{a}$ & $9.80 \mathrm{ab}$ \\
\hline 4 & Sucholaski & $0.290 \mathrm{a}$ & $299 \mathrm{a}$ & $220 \mathrm{a}$ & $33.73 \mathrm{a}$ & $7.1 \mathrm{ab}$ & $12.95 \mathrm{a}$ & $10.33 \mathrm{ab}$ \\
\hline 5 & M.tributary & $0.423 \mathrm{~b}$ & $447 \mathrm{~b}$ & $324 \mathrm{~b}$ & $77.45 \mathrm{c}$ & $9.7 \mathrm{bc}$ & $11.05 \mathrm{a}$ & $7.01 \mathrm{c}$ \\
\hline 6 & Bay & $0.416 \mathrm{~b}$ & $492 \mathrm{bc}$ & $362 \mathrm{bc}$ & $74.77 \mathrm{c}$ & $11.0 \mathrm{c}$ & $10.55 \mathrm{a}$ & $6.90 \mathrm{c}$ \\
\hline 7 & Bridge & $0.283 \mathrm{a}$ & $298 \mathrm{a}$ & $214 \mathrm{a}$ & $33.55 \mathrm{a}$ & $6.7 \mathrm{ab}$ & $12.25 \mathrm{a}$ & $10.28 \mathrm{ab}$ \\
\hline 8 & Wydminy & $0.289 \mathrm{a}$ & $302 \mathrm{a}$ & $220 \mathrm{a}$ & $34.44 \mathrm{a}$ & $7.1 \mathrm{ab}$ & $12.93 \mathrm{a}$ & $11.01 \mathrm{a}$ \\
\hline 9 & Drainage & $0.290 \mathrm{a}$ & $301 \mathrm{a}$ & $221 \mathrm{a}$ & $35.93 \mathrm{a}$ & $7.4 \mathrm{ab}$ & $12.87 \mathrm{a}$ & $9.98 \mathrm{ab}$ \\
\hline
\end{tabular}

Legend: $\mathrm{a}, \mathrm{b}, \mathrm{c}-$ homogeneous groups

\section{Conclusions}

The study demonstrated that the management method of the immediate catchment area of the lake (the forest and the high-density residential housing development in Sucholaski and Wydminy) did not significantly differentiate the analysed indices of water quality $(\mathrm{pH}$, $T D S, C O D, B O D_{5}$, dry residue and residue on ignition). This was probably due to the properly functioning wastewater management in these localities and to the order maintained on the beaches. It was found that water of the poorest quality was flowing into the lake through drainage ditches. Moreover, the following relationship was demonstrated: the greater the area being drained (drainage catchments of particular ditches), the worse parameters of the incoming water. The significantly lower values of the analysed indices found in the water outgoing from the lake, compared to its tributaries, clearly indicate the accumulative role in relation to the mineral and organic substances outgoing from agricultural areas. Consequently, this situation results in the deterioration of water quality, an increase in sediment accumulation and slow overgrowth of the water body, which was particularly noticeable in the lake bay fed by water of the main tributary. 


\section{References}

1. G. Papatheodorou, G. Demopoulou, N. Lambrakis, Ecol. Model 193 (2006)

2. P. Choudhary, J. Routh, G. J. Chakrapani, Environ. Earth Sci. 60 (2010)

3. M. V. Prasanna, S. Chidambaram, T. V. Gireesh, T. V. Jabir Ali, Environ. Earth. Sci. 63, 1 (2010)

4. A. S. Commault, G. Lear, S. Bouvier, L. Feilerd, J. Karacs, R. J. Weld, Biochem. Eng. J. 109 (2016)

5. M. Sepp, T. Kõiv, P. Nõges, T. Nõges, Sci. Total Environ. 610-611 (2018)

6. F. A. Khan, A.A. Ansari, The Botanical Review 71, 4 (2005)

7. V. B. Singh, A. L. Ramanathan, A. Mandal, Arabian J. Geosci. 9, 308 (2016)

8. M. Hayashi, W. L. Quinton, J. Pietroniro, J. J. Gibson. J. Hydrol. 296, 1-4 (2004)

9. O. F. Schoumans, W. J. Chardon, M. E. Bechmann, C. Gascuel-Odoux, G. Hofman, B. Kronvang, G. H. Rubæk, B. Ulén, J. M, Dorioz, Sci. Total Environ. 468-469 (2014)

10. APHA. Standard methods for the examination of water and wastewater $\left(21^{\text {st }} \mathrm{ed}\right.$. Washington, DC, New York: American Public Health Association, 2005)

11. Food and Agriculture Organization of the United Nations, Water Quality for Agriculture, Irrigation and Drainage (by Ayers RS, Westcot DW, 1994)

12. World Health Organization, Guidelines for Drinking-water Quality (2004)

13. E. Sienkiewicz, M. Gąsiorowski, Sci. Total Environ. 605-606 (2017)

14. V. Gopal, H. Achyuthan, M. Jayaprakash, Acta Ecol. Sin. 38 (2018)

15. P. Skonieczek, J. Koc, M. Duda, PECO 7, 1 (2013)

16. K. Sobczyńska-Wójcik, PECO 3, 2 (2009)

17. L. Przywara, A. Adamiec, M. Kuglarz, K. Grübel, PECO 11, 1 (2017)

18. A. G. B. Blankenberg, K. Haarstad, A. K. Sovik, Desalination 226, 1-3 (2008)

19. P. J. A. Withers, C. Neal, H. P. Jarvie, D. G. Doody, Sustainability 6, 9 (2014)

20. K. Yang, Z. Yu, Y. Luo, Y. Yang, L. Zhao, X. Zhou, Sci. Total Environ. 624 (2018) 